\title{
Traditional Techniques for the Management of Cactaceae in the Americas: The Relationship between Use and Conservation
}

\author{
Kamila Marques Pedrosa', Camilla Marques Lucena ${ }^{1}$, Reinaldo Farias Paiva de Lucena ${ }^{2}$, and Sérgio de Faria Lopes ${ }^{3}$ \\ ${ }^{1}$ Post-Graduate in Environmental Development, Universidade Federal da Paraíba, João Pessoa, Brazil. ${ }^{2}$ Laboratory of \\ Ethnobiology and Environmental Sciences, Universidade Federal da Paraíba, João Pessoa, Brazil. ${ }^{3}$ Laboratory of Ecology and \\ Conservation of Neotropical Dry Forests, Universidade Estadual da Paraíba, Campina Grande, Brazil. \\ *defarialopes@gmail.com
}

\begin{abstract}
Humans have used and coexisted with cacti in arid regions of North and South America for thousands of years. Species of the family Cactaceae possess physiological adaptations to arid and semi-arid climates that have allowed them to be used as a resource throughout the year by traditional peoples. The objective of this review is to present information on the uses and management of species of Cactaceae in the various regions of the Americas. This review provides information relevant to conservation policies regarding this important resource for local populations in semi-arid regions. To fully understand how management can influence cacti conservation, a knowledge gap regarding the traditional management of cacti needs to be addressed.
\end{abstract}

Received September 21, 2017

OPENӘACCESS

Accepted September 7, 2018

DOI 10.14237/ebl.9.2.2018.1117

Keywords Cacti, Local ecological knowledge, Ethnobotany, Management, Conservation

Copyright (c) 2018 by the author(s) licensee Society of Ethnobiology. This is an open-access article distributed under the terms of the Creative Commons Attribution-NonCommercial 4.0 International Public License (https://creativecommons.org/licenses/by-nc/4.0), which permits non-commercial use, distribution, and reproduction in any medium, provided the original author and source are credited.

\section{Introduction}

Traditional societies throughout the world have developed relationships with natural resources and established methods for their management, which are shaped according to local needs. These cultural practices reflect the types of interactions that occur between humans and their natural resources (Blancas et al. 2013). These interactions have important impacts on the diversity and distribution of nonhuman species, particularly plants. Therefore, the vast knowledge that traditional populations possess regarding different forms of exploitation and management of natural resources, especially plants, is the subject of numerous ethnobotanical studies (Albuquerque and Hanazaki 2010; Lopes 2017).

Among plants commonly managed by human populations are cacti (Cactaceae), which are used mainly during seasonal drought for human food, animal fodder, and medicine (Casas et al. 2014; Lucena et al. 2015). Cacti possess adaptive characteristics that allow them to grow and survive in conditions of low humidity typical of arid and semiarid regions (Godínez-Álvarez 2003; Ferreira et al.
2016; Larrea-Alcázar 2008). Cacti are one of the few sources of water available to human populations during periods of prolonged drought (Calvacanti and Resende 2007). The usefulness of cacti to human populations in these adverse environmental conditions favors the development of a close relationship between the two, which often takes the form of intentional or unintentional management (Blancas et al. 2013).

People select species of Cactaceae for use based on characteristics that offer a means of supplying the demand of consumption, with various types of harvesting and management practices that may or may not keep cacti intact (Casas et al. 2001). The intentional selection of favorable characteristics in different species is established by local people. Such practices include the protection of individuals in in situ or ex situ environments, which can lead to future phenotypic changes (Casas et al. 2007).

Conservation of biodiversity in tropical forests has allowed for a co-management system carried out by the government and local communities, recognizing that cultural perception is an important 
component for directing conservation actions (Diegues 2000; Norton 2001). This is especially true because the management techniques and methods adopted by local populations reflect adaptive ecological strategies that concentrate efforts to conserve resources important to the local economy (Tickton et al. 2002). Management of cacti species by local communities contributes to their distribution and species richness, which serve to ensure the economic and sociocultural success of the communities. However, improper exploitation can negatively affect management and increase risks to cacti populations (Velásquez-Mila et al. 2011).

The objective of the present review was to gather information on the types of uses and management of species of Cactaceae in various regions of the Americas. This review provides information relevant to conservation policies regarding this important resource for local populations in semi-arid regions.

\section{Cactaceae: Species Richness and Distribution in the Centers of Cacti Diversity}

The family Cactaceae is part of a group of perennial xerophilous plants with morphological, physiological, and functional adaptations that allow them to survive in hot climates (Sbrissa et al. 2012). Physiologically, species of Cactaceae are characterized by crassulacean acid metabolism (CAM), which is a specific type of metabolism that enables them to obtain high concentrations of $\mathrm{CO}_{2}$ (carbon dioxide) at night while the stomata are open, and store the carbon for photosynthesis during the day, when the stomata are closed; this reduces the loss of water to evapotranspiration (Taiz and Zeiger 2010). Due to adaptations to the environmental stresses caused by the edaphoclimatic conditions of the different regions where cacti are found, cacti have a competitive advantage in environments where water is a limiting factor, such as arid, semi-arid, and micro-epiphytic habitats (Taiz and Zeiger 2010).

Species of cacti possess thorns, which are modified leaves that protect against predator attack and prevent dehydration due to the loss of excessive water through high leaf surface area. In addition, the roots of cacti give them an advantage in water storage (Sbrissa et al. 2012). Their fruits vary in shape and size, and can be capsulate, tomentose, spiny, and scaly; white, red, yellow, or blue in color (Abreu 2008); carnose or dry; and dispersed by animals or by abiotic factors such as wind and water (Duarte et al. 2013).
There are about 2,000 species of Cactaceae across 124 genera distributed in tropical and temperate regions of the Americas (North, Central, and South America) (Rego et al. 2012), with four main centers of diversity (Taylon in Oldfield 1997): the United States, Mexico, the Andean Region, and Brazil (Figure 1). However, some species of cacti are found on other continents, such as Rhipsalis baccifera (J.M. Muell.) Stearn), which has been recorded on continental Africa, Madagascar, and Sri Lanka, where it is suspected to have been introduced by migratory birds (Cavalcante et al. 2013; Cerutti 1984).

Species of Cactaceae are distributed from Canada in North America south to the region of Patagonia in southern South America, including some Caribbean islands (Hunt and Taylor 1990). In Central America, Cactaceae is most diverse and widely distributed in Mexico, where there are around 900 species; Mexico is considered the second most diverse center of cacti in the world. Another center of diversity is the Andes of South America, mainly in Peru and Bolivia (Taylon in Oldfield 1997).

Brazil is considered the most diverse center of cacti in South America, with about 39 genera and 260 species, 187 of which are endemic (Zappi et al. 2016), with the state of Bahia being the center of diversity (Castro 2008). In Brazil, cacti are distributed among environments of Caatinga (a type of tropical dry forest ), tropical forest, Cerrado, rock outcrops, and restinga forests (Cruz 2011). In central Brazil, species of the family Cactaceae occur on rocky outcrops in the Cerrado, and in some areas of the Pantanal (Zappi et al. 2011). The west-central region of the country has 33 recorded cacti species, of which six are endemic; southern Brazil has a diversity of epiphytic cacti and is considered the second largest center of diversity in the country, but with only eight endemic species (PAN 2011).

The Caatinga ecoregion in the interior of northeast Brazil has the greatest number of individuals and species of cacti and the best edapho-climatic conditions for their growth (Bernardes 1999). Sixtytwo species of 19 genera of Caatinga cacti have been identified (Moro et al. 2014; Zappi et al. 2016). Of these, Pilosocereus pachycladus F. Ritter, Cereus jamacaru DC, and Pilosocereus gounellei (FAC Weber) are the species most used by local populations (male and female farmers [Duque 2004]). Rural human populations in the semi-arid regions of Brazil farm and raise livestock as their main subsistence; however, 
the climate does not favor economic security throughout the year, which causes people to use cacti to meet their needs (Duque 2004). In the absence of pasture, species of Cactaceae are used for animal fodder and have become a strong cultural component of these traditional populations (Lucena et al. 2015).

\section{Human Uses of Cacti in the Americas}

Species of Cactaceae are of potential use to human populations in several regions of the world (Blancas et al. 2010; Casas et al. 2014; Fuentes 2005; Lucena et al. 2012). The continuous manipulation of species by local communities for beneficial morphological and physiological characteristics contributes to their domestication, as is the case with the columnar cactus Stenocereus stellatus ((Pfeiff.) Riccob) in Mexico (Casas et al. 1999). One of the earliest records of a domesticated cactus species is from Mesoamaerica (Casas et al. 2003).

Historical records in Mexico from 1200 to 1400 years ago document a diversity of interactions between people and forest resources, with an emphasis on the cultivation and management of cacti for agricultural purposes (Casas et al. 2011). This relationship between local populations and their plant resources still occurs, and has been documented by several recent ethnobotanical studies (Lins-Neto et al. 2012; Lucena et al. 2015). Recent studies in Mexico (Blancas et al. 2010; Casas et al. 2001), Cuba (Fuentes 2005), Colombia (Fernández-Alonso 2006), the United States (Apadoca 2001), and Brazil (Lucena et al. 2012, Lucena et al. 2013; Lucena et al. 2015) have investigated the management of cacti (Casas et al. 1997, 2006; Lucena et al. 2013; Pérez-Negron et al. 2007) by different ethnic populations (local and traditional groups) who have used the resource for a variety of purposes (Lins-Neto et al. 2012).

The need for, and abundance of, cacti relate to how they are used in the local culture and economy (Lucena et al. 2015). Mexico is characterized by an ancient culture of use and commercialization of cacti, wherein traditional populations use them primarily for human consumption (Casas et al. 2006). Records for the Tehuácan-Cuicatlán valley, which is the center of origin of columnar cacti, document the use of cacti as food by local populations beginning 1400 years ago (Casas 2002; MacNeish 1967). In addition, there are records of very early ceremonial use of cacti in Mesoamerica, especially with regard to mescaline. Mescaline is a naturally occurring psychedelic alkaloid known for its hallucinogenic effects comparable to those of LSD and psilocybin. It occurs naturally in the Peyote cactus (Lophophora williamsii), the San Pedro cactus (Trichocereus pachanoi), and other members of Cactaceae (Crosby and McLaughlin 1973). The San Pedro cactus has been used for healing and religious divination in the Andes Mountains for over 3000 years, with strikingly realistic imagery found in early Chavín culture (ca. 900 BCE) (Burger 1992; Bussmann and Sharon 2006).

In the semi-arid region of Brazil (northeastern Brazil), traditional human populations are usually farmers who use the parts of cacti that are most useful for rural construction (such as slats for houses and hedges) and as fodder for animals, since they are one of the few plant resources available throughout the year (Lucena et al. 2012; Lucena et al. 2013). The fruits of cacti are used in human food and in the manufacture of sweets (Lucena et al. 2015), with cladodes and rackets being used for animal fodder (Figure 2).

\section{Traditional Management of Cacti}

Some species of cacti may be undergoing involuntary or unintentional management by traditional communities, specifically by the selection of individuals with characteristics that meet the demand of consumption, and which can be maintained with different types of exploitative cuttings (Casas et al. 2001). The intentional selection of favorable characteristics, by means of protecting certain individuals over others, can lead to phenotypic changes (Casas et al. 2007). In this way, local populations perform management techniques with cacti that preserve desirable (e.g., sweet, fleshy, and large fruits, large cladodes and rackets, fast growth) and/or eliminate undesirable phenotypes (e.g., cacti that do not have parts useful to the local population) depending on the particular edapho-climatic conditions of a given region (Blancas et al. 2010; Casas et al. 2006; 2017; Lucena et al. 2015).

Traditional management can be done in two distinct ways, in situ or ex situ, both of which favor plant abundance or diversity, and may include strategies including deforestation, burning, or even irrigation of desirable species (Casas et al. 2014). The strategies used change according to the biocultural issues present in a community, and can vary from vegetative propagation of the species to the reduction of competition from non-useful plants (Blancas et al. 2009; Clement et al. 2010; González-Insuasti et al. 2007), by means of practices that employ selection 
criteria aimed at eliminating undesirable phenotypes and increasing the availability of the preferentially used plants (Blancas et al. 2013).

In situ management is when plants are managed in their natural environments, and has three manifestations: tolerance, protection, and promotion. Tolerance is when the aim is to preserve individuals of the desired species before the preparation of the land (Casas et al. 1997, 2001, 2006). Protection is when competitors that may harm the species of interest are eliminated (e.g., pest removal), thereby guaranteeing and/or expanding useful plants (Casas et al. 1997, 2001, 2006). Management by promotion facilitates an increase in the number of individuals using techniques applied in their natural habitat, such as the application of fertilizers, manure, or compost, and the preparation of the soil and pruning (Casas et al. 1997, 2001, 2006).

On the other hand, ex situ management occurs within the anthropogenic fields with individuals being propagated through sowing and/or transplantation (Casas et al. 1997a). Ex situ management evolves over time through the selection of phenotypes that offer advantages, even when there are events that decrease the number of cacti (González-Insusti and Caballer 2007). It also involves the selection of species for different types of exploitation (Casas et al. 2006).

In Brazil, research concerning cacti management is emerging due to their importance in local economies and cultures, and the corresponding selection of individuals with economically viable characteristics (Arellano and Casas 2003). This kind of management has been recorded in the northeast region by Lucena et al. (2012, 2013, and 2015), who have sought to understand how traditional management techniques have contributed to the processes that determine genetic variation, as well as the possible domestication of Cereus jamacaru D.C. (mandacaru); C. jamacaru is one of several species of cacti that is used intensively by local populations in the semi-arid regions of Brazil. Lucena et al. (2015) point out that the overexploitation of cacti species, together with a lack of reforestation projects, has led to environmental problems that could result in decreased abundance of some species, including $C$. jamacaru.

Other types of management were also found in the Brazilian semi-arid region by Pedrosa (2018), who recorded management in natural environments (in situ), with the application of partial use and burning of the vegetative parts of the cacti in order to provide fodder for domestic animals. On the other hand, they found that species in domestic environments (ex situ) were positively affected by techniques that protected and promoted them, which favored their development and increased population density. These activities are linked to the ornamental value that cacti species provide to the local culture, thus facilitating their propagation and conservation. Understanding how local practices can improve sustainable livelihoods is essential for maintaining the natural cycle of local biodiversity within varied socio-ecological contexts.

\section{Perspective for Conservation}

Regions that harbor cacti tend to be in socioeconomically developing countries. These regions lack established conservation practices, especially regarding Cactaceae, for which there are species that are of conservation priority. This is the case for species of the genera Discocatus, Melocactus, Uebelmannia, and Parodia (Zappi et al. 2011), which are on the official endangered list of the Ministerio do Meio Ambiente Brasileiro (Brazilian Ministry of the Environment 2013).

By linking the need for conservation to local biocultural knowledge, traditional management can be used as an alternative approach to conservation. This is especially relevant for cacti because they are currently suffering pressure from destruction of habitat for agricultural purposes and the unrestrained use of cacti to meet rural needs. From this perspective, investigations into the processes and patterns of distribution, use, and management of cacti species are increasingly needed, particularly as climate change contributes to more severe droughts in arid and semi-arid regions. Furthermore, cacti conservation and management needs to be investigated carefully, taking into account risks to the genetic variability of cacti species.

\section{Acknowledgements}

Sérgio de Faria Lopes thanks the CNPq for the productivity grant awarded.

\section{Declarations}

Permissions: None declared.

Sources of Funding: CNPq (Conselho Nacional de

Desenvolvimento Científico e Tecnológico)

Conflicts of Interest. None declared. 


\section{References Cited}

Abreu, D. D. S. 2008. Germinação e Morfo-Anatomia do Desenvolvimento em Melocactus ernestii vauper e M. paucispinus heimem R.J. Paul (Cactaceae). Unpublished Master's Thesis, Instituto de Botânica, Universidade de São Paulo, São Paulo, Brazil.

Albuquerque, U. P., and N. Hanazaki. 2010. Recent Developments and Case Studies in Ethnobotany.

Sociedade Brasileira de Etnobiologia e Etnoecologia, Recife, Brazil.

Apadoca, P. 2001. Cactus Stones: Symbolism and Representation in Southern California and Seri Indigenous Folk Art Artifacts. Journal of California and Great Basin Anthropology 23:215-228.

Arellano, E., and A. Casas. 2003. Morphological Variation of Escontria chiotilla (Cactaceae) under Silvicultural Management in the Techuacán Valley, Central México. Genetic Resources and Crop Evolution 50:439-453.

Bernardes, N. 1999. As Caatingas. Estudos Avançados 13:35.

Blancas, J., A. Casas, R. Lira, and J. Caballero. 2009. Traditional Management and Morphological Patterns of Myrtillocactus schenckii (Cactaceae) in the Tehuacán Valley, Central Mexico. Economic Botany 63:375-387.

Blancas, J., A. Casas, S. Rangel-Landa, I. Torres, E. Pérez-Negrón, I. Solis, A. Delgado-Lemus, F. Parra, Y. Arellanes, J. Caballero, I. Cortes, R. Lira, and P. Dávila. 2010. Plant Management in the Tehuacán Cuicatlán Valley, México. Economic Botany 64:287302.

Blancas, J., A. Casas, D. Salicrup-Pérez, J. Caballero, and E. Veja. 2013. Ecological and Socio-Cultural Factors Influencing Plant Management in Náhuatl Communities of the Tehuacán Valley, Mexico. Journal of Ethnobiology and Ethnomedicine 9:39. DOI:10.1186/1746-4269-9-39.

Brazilian Ministry of the Environment (Ministério do Meio Ambiente Brasileiro). 2013. Instrução Normativa No. 6 [web page]. Available at: http:// www.cncflora.jbrj.gov.br/portal/pt-br/ listavermelha.

Burger, R. L. 1992. Chavin and the Origins of Andean Civilization. Thames and Hudson, New York, NY.

Bussmann, R. W. and D. Sharon. 2006. Traditional Medicinal Plant Use in Northern Peru: Tracking Two Thousand Years of Healing Culture. Jounal of
Ethnobiology and Ethnomedicine 2:47.

DOI:10.1186/1746-4269-2-47.

Casas, A., B. Pickersgill, J. Caballero, and A. ValienteBanuet. 1997. Ethnobotany and Domestication in Xoconchtli, Stenocereus stellatus (Cactaceae), in the Techuacán Valley and La Mixteca Baja, México. Economic Botany 51:279-292.

Casas, A., J. Caballero, C. Mapes, and S. Zarates. 1999. Manejo de la Vegetacíon Domesticacíon de Plantas y Origen de la Agricultura em Mesoamerica. Boletín de la Sociedad Botánica 61:17-3.

Casas, A., A. Valiente-Banuet, J.L Viveros, J. Caballero, L. Cortés, P. Dávila, R. Lira, and I. Rodríguez. 2001. Plant Resources of the TehuacánCuicatlán Valley, Mexico. Economic Botany 55:129_ 166.

Casas, A., and G. Barbera. 2002. Mesoamerica Domestication and Diffusion. In Cacti: Biology and Use, edited by P. Nobel, pp. 143-162. University of California Press, Los Angeles, CA.

Casas A., A. Otero-Arnaiz, E. Pérez-Negron, and A. Valiente-Banuet. 2003. Manejo y Domesticacíon de Cactáceas em Mesoamérica. Zonas Áridas 7:73-103. DOI:10.21704/za.v7i1.719.

Casas A., E. Pérez-Negron, A. Otero-Arnaiz, J. D. Lucio, M. E. Ruíz-Duron, F. Parra, and J. J. Blancas. 2006. Manejo Tradicional y Conservacíon de la Diversidade Biológica de Cactáceas Columnares. In Tópicos em Conservação e Etnobotânica de Plantas Alimentícias, edited by U. P. Albuquerque and C. de Fátima Almeida, pp. 75-92. Nupeea, Brazil.

Casas A., A. Arnaiz-Otero, E. Perrez-Negro, and A. Banuet-Valiente. 2007. In Situ Management and Domestication of Plants in Mesoamerica. Annals of Botany 100:1101-1115. DOI:10.1093/aob/mcm126.

Casas, A. 2011. Silvicultura y Domestication de Plants em Mesoamerica. In Plantas, Cultura y Sociedade. Estudio sobre la Relación entre Seres Humanos y Plantas em los Albores del Siglo XXI, edited by B. Rondom, S. Rebollar, J. Caballero, M. A. Martínez, and M. A. Pérez, pp. 123-157. Universidad Autónoma Metropolitana, Iztapalapa, México.

Casas A., A. Camou, A. Otero-Arnaiz, S. RangelLanda, J. Cruse-Sanders, L. Solís, I. Torres, A. Delgado, A. I. Moreno-Calles, M. Vallejo, S. Guillén, J. Blancas, F. Parra, B. Farfán-Heredia, X. AguirreDugua, Y. Arellanes, and E. Pérez-Negrón. 2014. Manejo Tradicional de Biodiversidad y Ecossistemas 
em Mesoamérica: El Valle de Tehuacán. Investigación Ambiental 6:23-44.

Casas, A., F. P. X. Aguirre-Dugua, S. Rangel-Landa, J. Rangel-Landa, M. Vallejo, A. I. Moreno-Calles, S. Guillén, I. Torres-García, A. Delgado-Lemus, E. Pérez-Negrón, C. J. Figueredo, J. M. Cruse-Sanders, B. Farfán-Heredia, L. Solís, A. Otero-Arnaiz, H. Alvarado-Sizzo, and A. Camou-Guerrero. 2017. Uso, Manejo, y Domesticación de Plantas em Mesoamérica. Una Estrategia de Investigación Estado del Conocimiento sobre los. In Domesticación en el Continente Americano. Investigación para el Manejo Sustentable de Recursos Genéticos en el Nuevo Mundo, edited by A. Casas, J. Torres-Guevara, and F. Parra, pp. 31-325. Universidad Nacional Agraria la Molina, Lima, Peru.

Castro, J. P. 2008. Número Cromossômicos em Espécies de Cactaceae Ocorrentes no Nordeste do Brasil. Universidade Federal da Paraíba, João Pessoa, Brazil.

Calvacante, A. 2013. Cactos do Semiárido do Brasil: Guia Ilustrado. Instituto Nacional do Semiárido, Brazil.

Cavalcanti, N. B., and G. M. Resende. 2007. Efeito de Diferentes Substratos no Desenvolvimento de Mandacaru (Cereus jamacaru P. DC.), Facheiro (Pilosocereus paclyycladus Ritter), Xiquexique (Pilosocereus goumellei (A.Webwr Ex K. Schum)Bly. Ex Rowl) e Coroa de Frade (Melocactus balnensis Britton \& Rose). Revista Caatinga 20:28-35.

Cerutti, V. 1984. Essai de Multiplication Interior de: Trichicereus pachanoi, Euphobia enopla, Euphorbia aeruginosa. Escola Superior de Agronomia de Purpan, Lisbon.

Clement, C. R., M. Cristo-Araújo, G. C. D'eeckenbrugge, A. A. Pereira, and D. PicançoRodrigues. 2010. Origin and Domestication of Native Amazonian Crops. Diversity 2:72-106.

Cruz, B. M. 2011. Estudos de Longevidade e Germinação em Sementes de Espécies do Gênero Melocactus (Cactaceae) em Morro do Chapéu, Chapada Diamantina, Bahia. Unpublished Master's Thesis, Universidade Federal de Feira de Santana, Feira de Santana, Brazil.

Crosby, D. M. and J. L. Mc Laughlin. 1973. Ltoya, 36.

Diegues, A. C. 2000. Etnoconservação: Novos Rumos para Conservação da Natureza nos Trópicos. HUCITEC \NUPAUB-USP, São Paulo, Brazil.
Duque, J. G. 2004. O Nordeste e as Lavouras Xerófilas, 4th edition. Banco do Nordeste do Brasil, Fortaleza, Brazil.

Hunt, D., and N. Tatlor. 1990. The Genera of Cactaceae-Progress Toward Consensus. Bradleya 8:85-107.

Fernández-Alonso, J. L. 2006. Nueva Espécie Colombiana de Browningia (Cactaceae, Cactoideae, Browningieae) Potencialidade Promissória Para el País. Revista de la Academia Colombiana de Ciências 3:19-30.

Ferreira, P. S. M., S. F. Lopes, and D. M. M. Trovão. 2016. Patterns of Species Richness and Abundance Among Cactus Communities Receiving Different Rainfall Levels in the Semiarid Region of Brazil. Acta Botanica Brazilica 30:569-576. DOI:10.1590/0102-33062016abb0084.

Fuentes, V. R. 2005. Etnobotânica de Cactáceas em Cuba. In Memorias del Taller Conservacion de Cactos Cubanos, edited by L. R. González Torres, A. Palmadora, and A. Rodriguez, pp. 15-24. Jardín Botánico Nacional, University of Havana, Cuba.

Godinez-Alvarez, H. 2003. Demographic Trends in the Cactaceae. The Botanical Review 69:173-203. DOI:10.1663/0006-8101(2003)069[0173:DTITC] 2.0.CO;2.

González-Insuasti, M., and J. Caballer. 2007. Managing Plant Resources: How Intensive Can it Be? Human Ecology 35:303-314. DOI:10.1007/ s10745-006-9063-8.

Larrea-Alcázar, D. M. 2008. Spatial Associations Between Two Globose Cacti and Two Dominant Mimosoid Bushes in a Tropical Semiarid Enclave. Ecotrópicos 21:97-105.

Lins-Neto, E. M. F., N. Peroni, C. M. C. Maranhão, M. I. S. Maciel, and U. P. Albuquerque. 2012. Analysis of Umbu (Spondias tuberosa Arruda (Anacardiaceae)) in Different Landscape Management Regimes: A Process of Incipient Domestication? Environmental Monitoring and Assessment 184:4489-4499. DOI:10.1007/510661011-2280-7.

Lopes, S. F. 2017. The Other Side of Ecology: Thinking About the Human Bias in our Ecological Analyses for Biodiversity Conservation. Ethnobiology and Conservation 6:1-24. DOI:10.15451/ ec2017086.14124. 
Lucena, C. M., G. M. Costa, R. F. Sousa, T. K. N. Carvalho, N. A. Marreiros, C. A. B. Alves, D. D. Pereira, and R. F. P. Lucena. 2012. Conhecimento Local sobre Cactáceas em Comunidades Rurais na Mesorregião do Sertão da Paraíba (Nordeste, Brasil). Biotemas 25:281-291. DOI:10.5007/2175$7925.2012 \mathrm{v} 25 \mathrm{n} 3 \mathrm{p} 281$.

Lucena, C. M., R. P. F. Lucena, G. M. Costa, T. K. N. Carvalho, G. G. S. Costa, R. R. N. Alves, D. D. Pereira, J. E. S. Ribeiro, C. A. B. Alves, Z. G. M. Quirino, and E. M. Nunes. 2013. Use and Knowledge of Cactaceae in Northeastern Brazil. Journal of Ethnobiology and Ethonomedicine 62:1-11. DOI:10.5007/2175-7925.2012v25n3p28.

Lucena, C. M., T. K. N. Carvalho, J. E. S Ribeiro, Z. G. M. Quirino, A. Casas, and R. F. P. Lucena. 2015. Conhecimento Botânico Tradicional sobre Cactáceas no Semiárido do Brasil. Gaia Scientia 9:77-90.

McNeish, R. S. 1967. A Summary of the Subsistence. In The Prehistory of the Tebuacán V alley, edited by D. S. Byers, pp. 290-231. University of Texas Press, Austin, TX.

Moro, M. F., E. N. Lughadha, D. L. Filer, F. S. Araújo, and F. R. Martins. 2014. Catalogue of the Vascular Plants of the Caatinga Phytogeographical Domain: A Synthesis of Floristic and Phytosociological Surveys. Phytotaxa 160:1-18. DOI:10.11646/phytotaxa.160.1.1.

Norton, B. G. 2001. Conservation Biology and Environmental Values: Can There be a Universal Earth Ethic? In Protecting Biological Diversity: Roles and Responsibilities, edited by C. Potvin, M. Kraenzel, and G. Seutin, pp. 71-102. McGill-Queen's, University Press, Montreal.

Pedrosa, K. P. 2018. Uso e Manejo Tradicional de Cactaceae no Semiárido da Paraíba, Nordeste do Brasil. Dissertação de Mestrado (Desenvolvimento do Meio Ambiente) Universidade Federal da Paraíba, João Pessoa, Brazil.

Pérez-Negrón, E., and A. Casas. 2007. Use, Extraction Rates, and Spatial Availability of Plant Resources in the Tehuacán-Cuicatlán Valley, Mexico: The Case of Santiago Quiotepec, Oaxaca. Journal Arid Environmental 70:356-379. DOI:10.1016/j.jaridenv.2006.12.016.
Plano de Ação Nacional Para a Conservação das Cactáceas (PAN). 2011. Instituto Chico Mendes de Conservação da Biodiversidade, Brasília, Brazil .

Rego, J. O. 2012. Reproductive Biology of a Highly Endemic Species: Cipocereus laniflorus. Taylor, N.P. and D. Zappi (Cactaceae). Acta Botanica Brasilica 26:243-250. DOI:10.1590/S010233062012000100023.

Sbrissa, F. C., and A. G. C. Melo. 2012. Conservação Morfológica e Conservação de Anthocereus odorus F. Titter. Revista Eletrônica de Engenharia Florestal 20:1.

Taiz, L., and E. Zeiger. 2010. Fisiologia Vegetal, 4th edition. Translated by Eliane Romanato Santarém et al. Artmed, Porto Alegre, Brazil.

Taylor, N. P. 1997. Cactaceae. In Cactus and Succulent Plants: Status Survey and Conservation Action Plan, edited by S. Oldfield, pp. 17-20, 199-202. IUCN/ SSC Cactus and Succulent Specialist Group, Gland, Switzerland.

Tickton, T. G., C. Lisley, C. Dalle, and S. Johns. 2002. Participatory Ethnoecological Research for Conservation: Lessons from Case Studies in Mesoamerica. In Ethnobiology and Biocultural Diversity: Proceedings of the Seventh International Congress of Ethnobiology, edited by J. R. Stepp, F. S. Wyndham, and R. K. Zarger, pp. 575-584. University of Georgia Press, Athens, GA.

Velásquez-Mila, D., A. Casas, J. Torres-Guevara, and A. Cruz-Soriano. 2011. Ecological and SocioCultural Factors Influencing In Situ Conservation of Crop Diversity by Traditional Andean Households in Peru. Journal of Ethnobiology and Ethnomedicine 7. DOI:10.1186/1746-4269-7-40.

Zappi, D., N. Taylor, and J. Lorocca. 2011. Plano de Ação Nacional Para Conservação das Cactáceas. Instituto Chico Mendes de Conservação da Biodiversidade, Brazil.

Zappi, D., N. Taylor, M. R. Santos, and J. Larocca. 2016. Jardim Botânico do Rio de Janeiro. Lista de espécies da Flora do Brasil: Cactaceae. [web page]. Available at: http://floradobrasil.jbrj.gov.br/jabot/ floradobrasil/FB70. Accessed on May 10, 2017. 